\title{
Prokaryotic lifestyles in deep sea habitats
}

\author{
Federico M. Lauro · Douglas H. Bartlett
}

Published online: 1 December 2007

(C) Springer 2007

\section{Erratum to: Extremophiles}

\section{DOI 10.1007/s00792-006-0059-5}

The original version of this article unfortunately contained a mistake. Two errors appeared in the article. In the first sentence of the introduction, in the phrase "...is believed to contain $6.5 \times 10^{28}$ cells $\mathrm{ml}^{-1}$ ", there should be no unit, i.e. " $\mathrm{ml}^{-1}$ " should be omitted. In Table 1 , the $P_{\mathrm{opt}}$ for Photobacterium profundum SS9 has been incorrectly reported as 0.1 . It should be 28 .

The online version of the original article can be found under doi:10.1007/s00792-006-0059-5.

F. M. Lauro · D. H. Bartlett ( $\square)$

Scripps Institution of Oceanography,

Center for Marine Biotechnology and Biomedicine,

Marine Biology Research Division,

University of California,

8750 Biological Grade, San Diego,

La Jolla, CA 92093-0202, USA

e-mail: dbartlett@ucsd.edu 